Original

\title{
Human osteoblast-like cell spreading and proliferation on Ti-6Al-7Nb surfaces of varying roughness
}

\author{
Thanaphum Osathanon ${ }^{1,2)}$, Kritchai Bespinyowong ${ }^{2)}$, Mansuang Arksornnukit ${ }^{3)}$, \\ Hidekazu Takahashi ${ }^{4)}$ and Prasit Pavasant ${ }^{1,2)}$ \\ ${ }^{1)}$ Developing Research Unit of Genetic and Anatomical Analyses of Craniofacial Structures and \\ Mineralized Tissue Research Unit, Chulalongkorn University, Bangkok, Thailand \\ ${ }^{2)}$ Department of Anatomy, Faculty of Dentistry, Chulalongkorn University, Bangkok, Thailand \\ ${ }^{3)}$ Department of Prosthodontics, Faculty of Dentistry, Chulalongkorn University, Bangkok, Thailand \\ ${ }^{4)}$ Advanced Biomaterials, Department of Restorative Sciences, Division of Oral Health Sciences, \\ Graduate School, Tokyo Medical and Dental University, Tokyo, Japan
}

(Received 5 October and accepted 2 December 2010)

\begin{abstract}
There have been a number of attempts to modify the surface of dental implants to improve osseointegration. These modifications include alterations of surface chemistry and roughness. The purpose of this study was to examine the early response of human osteoblast-like cells placed on Ti-6AI-7Nb disks that had a similar grooved surface topography and three different levels of surface roughness $(\mathrm{Ra}=$ 0.0374, 0.0911, and $0.2435 \mu \mathrm{m}$ ). Cultures of human osteoblast-like cells revealed no significant difference in initial cell attachment among the various surfaces; however, cell spread was greater on rough surfaces than on glass slides and smoother surfaces. In addition, cell proliferation and Ki-67 expression were increased when cells were cultured on rough surfaces. These results suggest that a greater $\mathrm{Ti}-6 \mathrm{Al}-7 \mathrm{Nb}$ surface roughness support the initial spread and proliferation of human osteoblast-like cells. Thus, modification of the surface roughness of dental implants might hasten osseointegration. (J Oral Sci 53, 23-30, 2011)
\end{abstract}

Keywords: Ti-6Al-7Nb; surface roughness; cell spreading; cell proliferation.

Correspondence to Dr. Thanaphum Osathanon, Department of Anatomy, Faculty of Dentistry, Chulalongkorn University, HenriDunant Rd. Pathumwan, Bangkok, 10330 Thailand

Tel: +66-2-218-8884

Fax: +66-2-218-8870

E-mail: osathanon.t@gmail.com

\section{Introduction}

The inadequate mechanical properties of commercial pure titanium (cpTi) can lead to clinical failure of dental materials (1). The titanium alloy titanium 6-aluminium 4vanadium (Ti-6Al-4V) was developed to improve the mechanical properties of implants. However, the potential toxicity of vanadium limited its clinical use (2). This led to the use of titanium 6-aluminium 7-niobium (Ti-6Al-7Nb) as the material of choice in dental applications (3-5). The mechanical strength of Ti-6Al-7Nb is superior to that of cpTi (6). It also highly resistant to corrosion (7) and wear (8).

Several biological responses to Ti-6Al-7Nb have been reported. Rogers et al. (10) observed that similar levels of prostaglandin $\mathrm{E}_{2}\left(\mathrm{PGE}_{2}\right)$ were released from human monocytes in response to Ti-6Al-7Nb and cpTi. However, these levels were significantly lower than those observed in response to Ti-6Al-4V (9). Shimajo et al. reported that human gingival fibroblasts similarly adhered, spread, and proliferated on Ti-6Al-7Nb and cpTi. In addition, shortterm in vivo implantation resulted in a transient inflammation response to Ti-6Al-7 $\mathrm{Nb}$ that resembled the response to cpTi, with no obvious adverse biological effects $(11,12)$. Our group previously reported that $\mathrm{Ti}-6 \mathrm{Al}-7 \mathrm{Nb}$ promoted better osteoblast-like cell spreading as compared with cpTi (13). Moreover, in a short-term evaluation, osteoblastlike cells seeded on Ti-6Al-7Nb exhibited higher fibronectin and osteopontin expression than cells seeded on glass 
slides and cpTi (13). These results suggest that Ti-6Al-7Nb is biocompatible and supports early osteoblast-material interaction. Thus, it is a promising candidate material for use in implant dentistry.

Various surface parameters have been shown to influence osteoblast behavior on dental implant materials, including surface topography, roughness, and chemistry (14-17). Modification of titanium surface chemistry using ultraviolet (UV) light treatment resulted in increased rat bone marrow-derived cell attachment, spread, proliferation, and differentiation (18). Moreover, UV treatment might facilitate osseointegration and implant stability (18). Schwartz et al. described the effect of surface roughness on human osteoblast-like cell behavior (19). When osteoblast-like cells were cultured on a grit-blasted titanium surface $(\mathrm{Ra}=2.0-3.3 \mu \mathrm{m})$, levels of osteocalcin, transforming growth factor- $\beta 1$, and osteoprotegerin secretion were higher than in cells cultured on a smooth surface ( $\mathrm{Ra}$ $=0.2 \mu \mathrm{m})(19)$. In addition, they noted that the torque required to remove titanium screws from bone was higher for a grit-blasted surface than a smooth surface (19). The findings of Schwartz et al. confirmed those of previous reports that suggested the potential positive effect of surface roughness on osteoblast behavior in the promotion of osseointegration (14,20-22). However, a number of reports have indicated that the roughness of titanium surfaces is not associated with osseointegration (23-26).

The aim of this study was to evaluate the effect of Ti$6 \mathrm{Al}-7 \mathrm{Nb}$ surface roughness on the biological response of osteoblast-like cells, as determined by assessing in vitro cell attachment, spreading, and proliferation.

\section{Materials and Methods \\ Preparation of titanium disks}

Ti-6Al-7Nb (T-alloy, Tough, GC Corp., Tokyo, Japan) disks measuring $12 \mathrm{~mm}$ in diameter and $2 \mathrm{~mm}$ in thickness were cast. To obtain different surface roughnesses, the specimens were polished using $1200-$, 400-, or 180-grit SiC paper in a polishing machine (DPS 3200, IMPTECH, Boksburg, South Africa). The obtained specimens were further defined as Ti1200, Ti400 and Ti180 according to the roughness of $\mathrm{SiC}$ paper, respectively. Glass cover slips were used as the control. The specimens were cleaned using ultrasonic cleanser for $1 \mathrm{~h}$, then rinsed with $70 \%$ ethanol, followed by three rinses with deionized water. The specimens were then sterilized by autoclave.

\section{Measurement of surface roughness}

Surface roughness was measured by using a contact profilometer (Talyscan 150, TaylorHobson, Leicester, UK). Surface roughness (Ra) measurements were randomly
Table 1 Surface roughness of investigated specimens

\begin{tabular}{ll}
\hline Material & $\mathrm{Ra}(\mu \mathrm{m})$ \\
\hline Glass slide & $0.0138 \pm 0.0010$ \\
Ti1200 & $0.0374 \pm 0.0087$ \\
Ti400 & $0.0911 \pm 0.0200^{*}$ \\
Ti180 & $0.2435 \pm 0.0690^{*}$ \\
\hline *Significant difference between experimental group and control $(P<0.05)$.
\end{tabular}

taken at five different locations on each disk $(n=6)$, with the disk spinning in one direction at a speed of $2.0 \mathrm{~mm} / \mathrm{s}$. Computer simulation of surface topography was performed using the software provided by the manufacturer.

\section{Cell culture}

SaOS-2 cells (a human osteoblast-like cell line) were kindly provided by Professor Erik Thompson, St. Vincent's Institute of Medical Research, and seeded on specimens at a density of 80,000 cells per disk. The cells were maintained in Dulbecco's modified Eagle's medium (DMEM) containing 10\% fetal calf serum (FCS), $2 \mathrm{mM}$ L-glutamine, $100 \mathrm{unit} / \mathrm{ml}$ penicillin, $100 \mu \mathrm{g} / \mathrm{ml}$ streptomycin, and $5 \mu \mathrm{g} / \mathrm{ml}$ amphotericin B in conditions of $100 \%$ humidity, $37^{\circ} \mathrm{C}$, and $5 \%$ carbon dioxide. The medium was changed every $48 \mathrm{~h}$.

\section{Scanning electron microscopic analyses}

At 20 min after seeding, cells were fixed with $2.5 \%$ glutaraldehyde (Sigma, St Louis, MO, USA) in phosphatebuffered saline (PBS) for $30 \mathrm{~min}$ and rinsed with $0.1 \mathrm{M}$ PBS. Samples were dehydrated, processed for critical point drying (CPD 7501, FISONS Instrument, West Sussex, UK), and sputter-coated with gold. Cell morphology was evaluated using a scanning electron microscope (JSM 5401LV, JEOL, Tokyo, Japan).

\section{Cell attachment assay}

The number of cells attached to titanium disks was determined by counting cells at 350x magnification in five fields $(n=6)$. Two different cell populations were evaluated. Cell attachment and spreading were determined using criteria modified from Lumbikanonda and Sammons (27) as follows: stage 1, round cells with few filopodia; stage 2, numerous focal cytoplasmic extensions from cells; stage 3, cells with circumferential cytoplasmic spreading; and stage 4, polygonal full spreading and flattening of cells. Cells exhibiting stage 1 attachment were classified as initially attached cells, whereas those showing stage 2, 3, or 4 attachment were classified as spreading cells. The number of cells at each stage was expressed as a percentage of the total number of cells. 


\section{Cell proliferation assay}

At $24 \mathrm{~h}$ and $72 \mathrm{~h}$, cells on materials were fixed and then stained using 4',6-diamidino-2-phenylindole dihydrochloride (DAPI) to identify cell nuclei. Pictures of cells were then randomly taken at 20x magnification. Nuclei were counted and expressed as number of nuclei per field.

$\mathrm{Ki}-67$ immunofluorescence was used as a protein marker of cell proliferation. Briefly, cells seeded on material were fixed with cold ethanol. The specimens were then blocked using horse serum for $1 \mathrm{~h}$. Primary antibody (Ki-67 dilution 1:100) was incubated overnight at $4^{\circ} \mathrm{C}$, and FITCconjugated secondary antibody was used to visualize protein expression.

\section{Statistical analyses}

The experiments were performed in triplicate. Data are expressed as mean \pm standard deviation. Statistical analysis was performed using one-way analysis of variance (ANOVA) follow by the Tukey HSD test. A $P$ value less than 0.05 was considered to indicate statistical significance.

\section{Results \\ Analysis of surface topography \\ The table shows the mean Ra values of the investigated specimens. The Ra values for the glass slide and Ti1200 were not statistically different. However, the Ra values of both Ti400 and Ti180 significantly differed from those of the glass slides and Ti1200. In addition, computer-generated images revealed the grooved surface topography in Ti400}

and Ti180 specimens, as shown in Fig. 1. In contrast, the surfaces of the glass slide and Ti1200 appeared relatively smooth, with no longitudinal grooving.

\section{Cell attachment and spreading}

We examined the number of attached cells on surfaces after seeding for $20 \mathrm{~min}$. SEM observation revealed round cells and cells with extending pseudopodia (Fig. 2A). There was no statistical difference in the number of attached cells on the respective surfaces (Fig. 2B).

Figure 3A shows the morphology of initially attached cells (left) and spreading cells (right). As shown in Fig. $3 \mathrm{~B}$, the percentage of initially attached cells was significantly lower for Ti400 and Ti180 surfaces than for the control and Ti1200 surfaces. However, the percentages of spreading cells were significantly higher on the surfaces with higher Ra value, which suggests that rough surfaces provide better support for cell spreading.

Cells on glass slides extended several short filopodia (Fig.4A) and displayed circumferential cytoplasmic spreading (Fig. 4B). In contrast, cells on Ti400 and Ti180 were not flat, but extended numerous filopodia over the grooving of the titanium surface (Fig. 4C, D).

\section{Cell proliferation}

Figure 5 shows cell attachment on Ti-6Al-7Nb at different surface roughnesses after $24 \mathrm{~h}$ and $72 \mathrm{~h}$. At $72 \mathrm{~h}$, the number of cells on the titanium surfaces was higher than at $24 \mathrm{~h}$. In addition, cell attachment tended to be higher
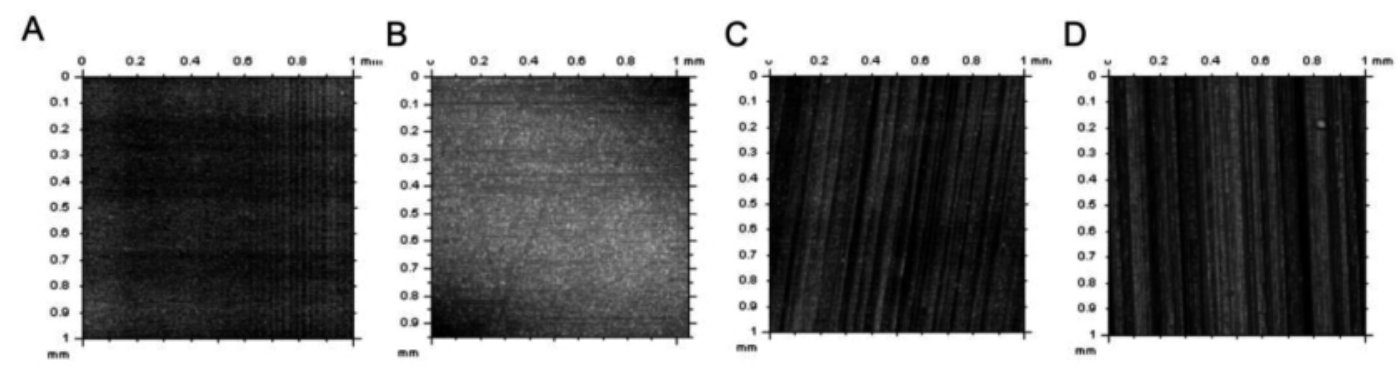

\section{E}

$\mathrm{F}$

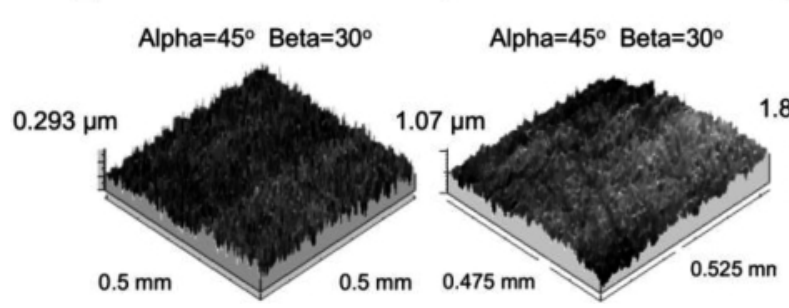

\section{G}

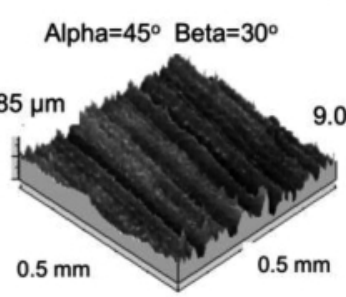

$\mathrm{H}$

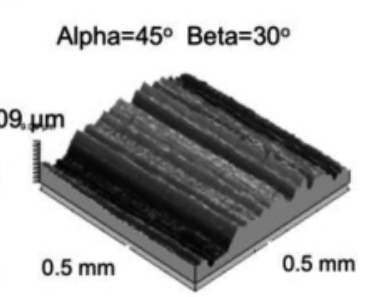

Fig. 1 Images generated by Talyscan150 software showing the surface of the investigated materials in two dimensions (A-D) and three dimensions (E-H).

(A, E) glass slide control, (B, F) Ti1200, (C, G) Ti400, and (D, H) Ti180. 
on the rough surfaces, i.e., Ti400 and Ti180. However, the difference was statistically significant only for Ti180 at both $24 \mathrm{~h}$ and $72 \mathrm{~h}$. In addition, cells on Ti-400 and Ti180 tended to be aligned with the grooves on the titanium surface (Fig. 5c, d, g, h).

Upon immunocytochemical staining with Ki67, an

A

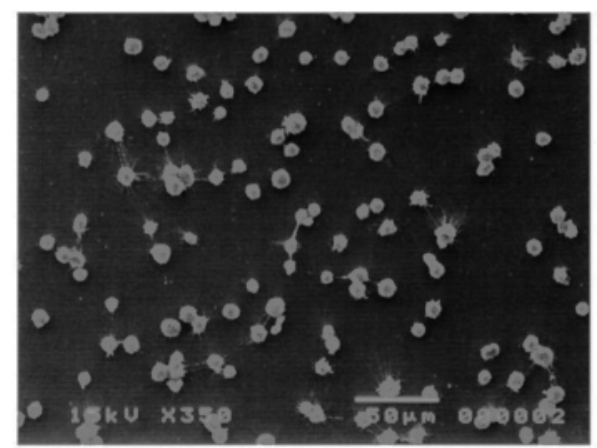

B

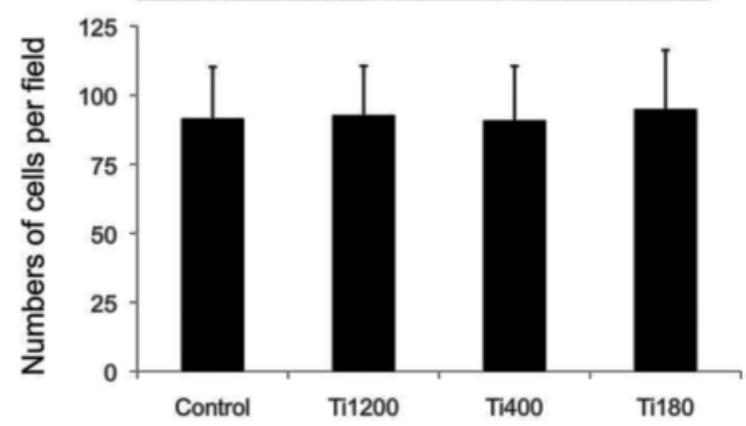

Fig. 2 Scanning electron micrograph of SaOS-2 cells attached to material at $20 \mathrm{~min}$ (A). The graph shows the number of cells attached to surfaces of varying roughness at $20 \min (\mathrm{B})$. increase in Ki-67 expression was observed in the nuclei of cells seeded on Ti400 and Ti180 (Fig. 6), which suggests that a rougher surface promotes cell proliferation.

\section{Discussion}

A long-term case series showed that threaded, surfaceroughened implants had the highest rate of clinical success, which suggests an important role for surface roughening on dental implant survival (28). In the present study, we fabricated Ti-6Al-7Nb disks with uniform parallel grooves and three surface roughnesses (Ra range, 0.037-0.243 $\mu \mathrm{m})$. We found that modification of the surface roughness
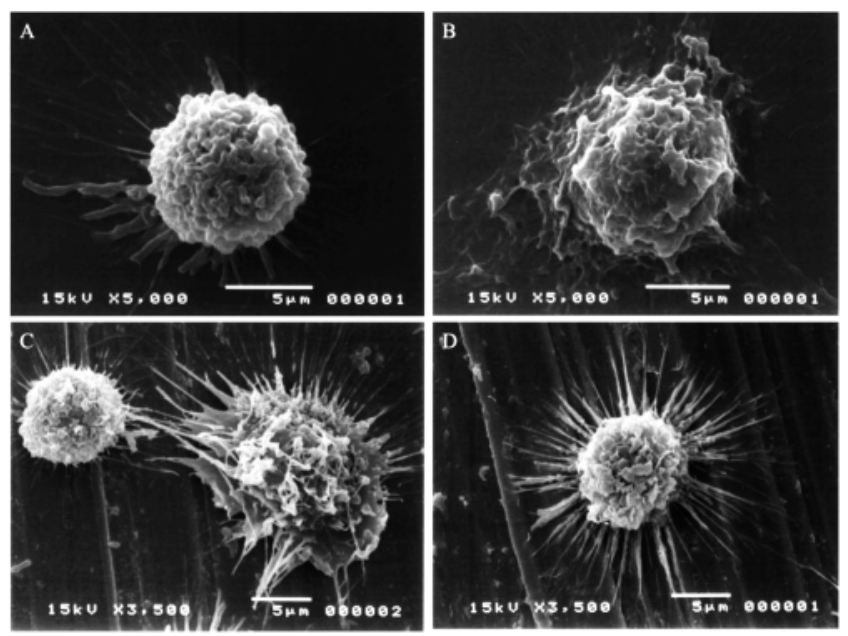

Fig. 4 Scanning electron micrographs of cell morphology at 20 min after seeding on glass slide (A, B), Ti400 (C) and Ti180 (D).
A

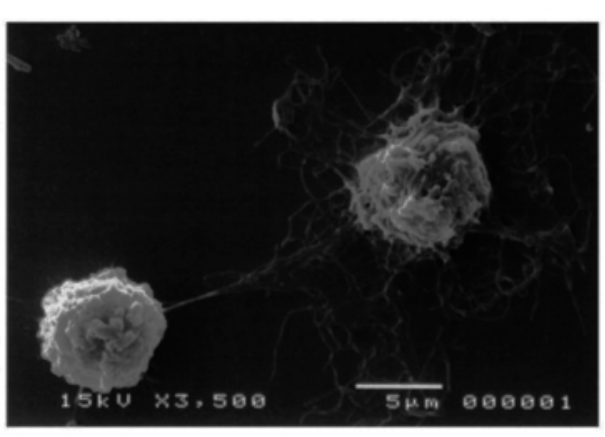

B

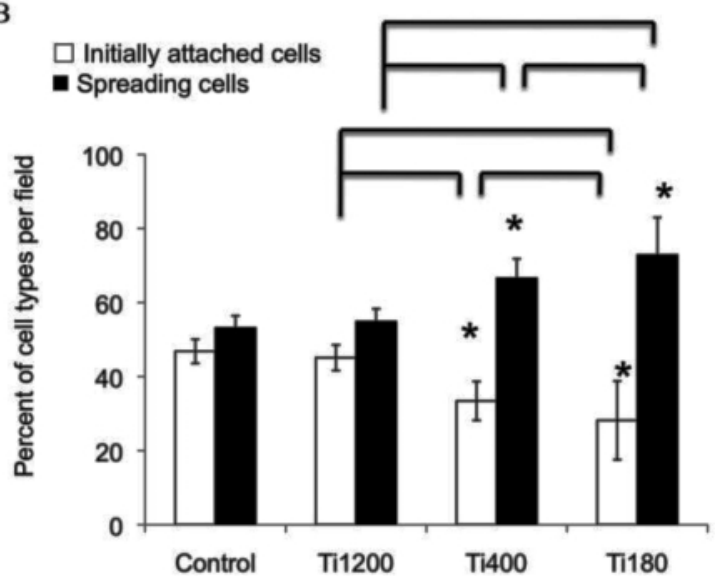

Fig. 3 Scanning electron micrograph of cell morphology during initial attachment (left) and spreading (right) (A). Initially attached and spreading cells on surfaces of varying roughness were counted and expressed as percentages, as shown in the graph (B). Horizontal brackets indicate a statistically significant difference between groups $(P<0.05)$. Asterisks indicate a statistically significant difference as compared with control $(P<0.05)$. 
A $24 \mathrm{~h}$

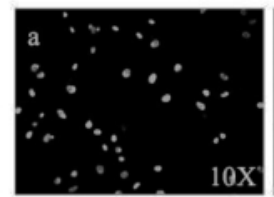

Ti 1200

Ti 400

Ti 180
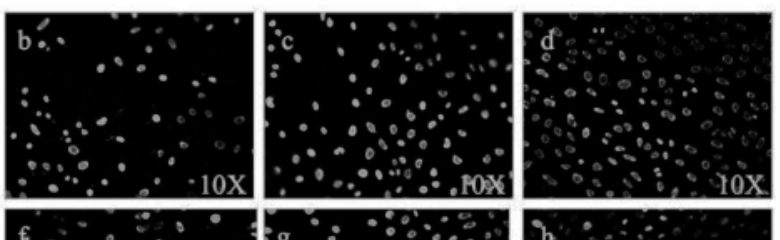

$72 \mathrm{~h}$
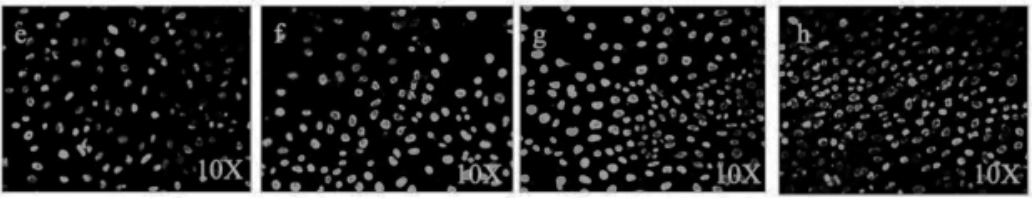

B

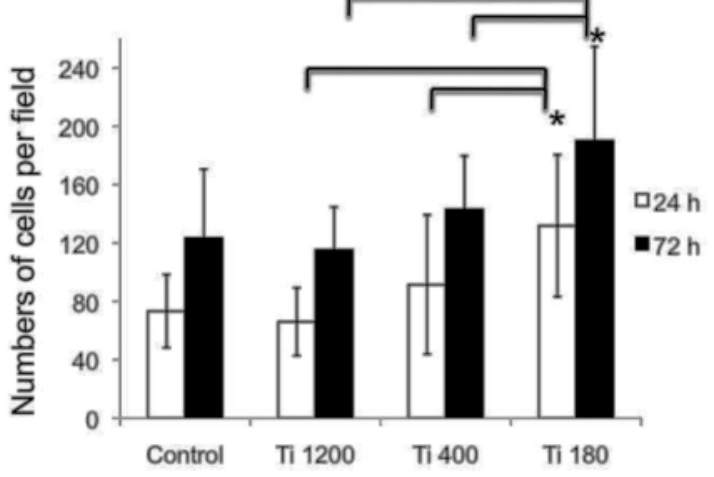

Fig. 5 DAPI staining of SaOS-2 cells on different surfaces at $24 \mathrm{~h}$ and $72 \mathrm{~h}$ after seeding (A). The total numbers of cells per field were counted and are shown in the graph (B). Horizontal brackets indicate a statistically significant difference between groups $(P<0.05)$. Asterisks indicate a statistically significant difference as compared with control $(P<0.05)$.
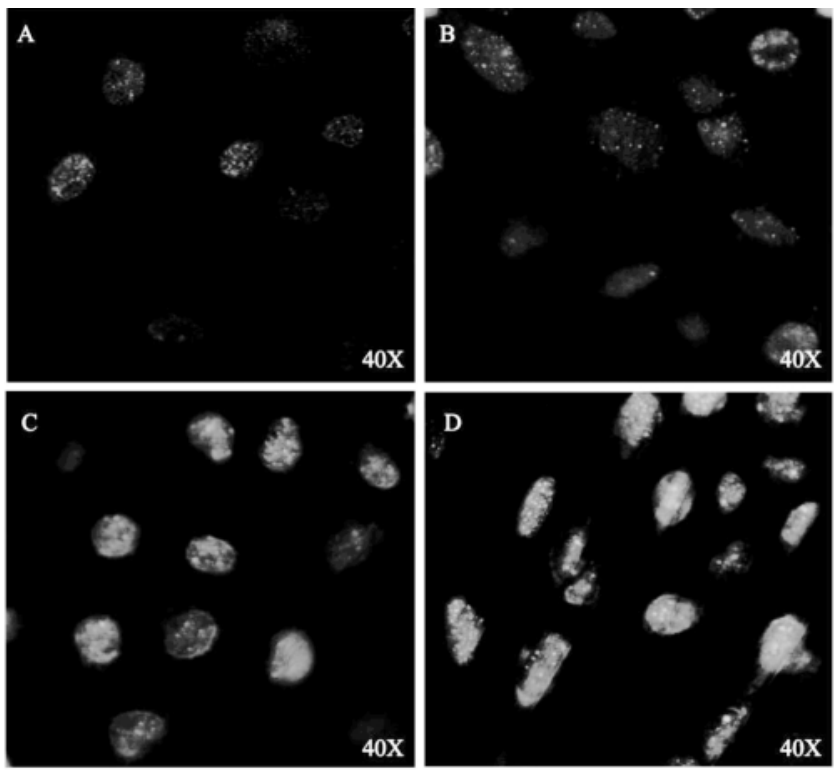

Fig. 6 Ki-67 immunofluorescence staining of SaOS-2 cells on glass slide (A), Ti1200 (B), Ti400 (C) and Ti180 (D).

of Ti-6Al-7Nb disks had no effect on osteoblast attachment. However, cell spreading was greater on rough surfaces than on smooth surfaces and glass slides. Moreover, greater cell proliferation was noted when osteoblasts were cultured on rough surfaces.

There are discrepancies in the findings of studies that examined the effect of surface roughness on cell attachment, proliferation, and differentiation. These inconsistencies may be due to differences in the cell type used, culture conditions, serum concentration, surface fabrication methods, sterilization techniques, and type of substratum.

One study showed that surface roughness had no effect on cell attachment (29), while others reported an increase in the number of cells attached on rough surfaces (20-21). In the present study, we found no significant association between cell attachment and surface roughness. Our findings are similar to those of Rosa and Beloti, who reported that primary rat and human bone marrow cell attachment was not affected when cells were cultured on cpTi and Ti-6Al-4V of varying surface roughness (Ra range, 0.23-1.98 $\mu \mathrm{m})(30,31)$. There are two possible explanations for the lack of an association between cell attachment and surface roughness. First, the serum concentration used in culture medium may affect early cell attachment. Lee et al. (32) reported that neonatal rat 
calvarial osteoblast attachment on polished and grit-blasted Ti-6Al-4V surfaces was comparable when cells were cultured in medium containing $10 \% \mathrm{FBS}$; however, the number of cells attached on the smooth surface was significantly higher when cultured in the presence of $4 \%$ FBS. A second possible explanation is that the pattern and degree of surface roughness influenced cell response. Deligianni et al. observed a significant difference in cell attachment at 30 min after cell seeding on Ti-6Al-4V surfaces of different roughness $(\mathrm{Ra}=0.32 \mu \mathrm{m}$ and 0.87 $\mu \mathrm{m})$. This suggests that human bone marrow cells were sensitive to an approximately $0.60-\mu \mathrm{m}$ difference in surface roughness (33). In the present study, however, the difference in Ra was less than $0.20 \mu \mathrm{m}$.

Some studies have suggested that, in addition to surface roughness, other surface properties, such as surface energy (34) and surface chemistry $(17,18)$, affect initial cell response. One study noted that, immediately after placing a titanium dental implant, plasma protein adsorption occurred on the surface of the implant, after which, surrounding host cells interacted with the adsorbed proteins, thereby further regulating cell behavior (35). Deligianni et al. (33) reported that a rough Ti-6Al-4V surface adsorbed a higher amount of total protein from culture medium containing $10 \%$ FCS than did a smooth surface. Rough surfaces do not simply regulate initial cell response by providing more surface area for protein adsorption; they have been shown to preferentially adsorb greater amounts of fibronectin, while smooth surfaces adsorb greater amounts of bovine serum albumin (33). Fibronectin was shown to promote cell adhesion and reorganization of actin microfilaments (36). Previously, our group reported that $\mathrm{SaOS}-2$ cells seeded on Ti-6Al-7Nb with a similar surface roughness to cpTi expressed more fibronectin at both the mRNA and protein levels (13). Moreover, cell spreading on Ti-6Al-7Nb was superior to that on cpTi (13). Together, these findings indicate that substratum composition affects fibronectin secretion and, thus, cell spreading (13).

In this study, we observed greater cell spreading on rough Ti-6Al-7Nb surfaces than on smooth surfaces, but the total number of attached cells was similar on these different surfaces. Similarly, Kim et al. (37) reported that MG63 osteoblast-like cells had a spherical, dome-like shape on a smooth Ti-6Al-4V surface and that cells were able to spread over and cover a rough Ti-6Al-4V surface. They concluded that the rough titanium surface affected osteoblast spreading (37). Horbett and Schway (38) reported that cell attachment was not correlated with fibronectin adsorption, but that cell spreading was well correlated with fibronectin adsorption by the substrate in the presence of serum. Thus, we hypothesize that rough surfaces adsorb more fibronectin, thereby facilitating cell spreading. However, further investigation is required to confirm this hypothesis.

Early cell attachment has been described as a passive phenomenon, but late-stage cell spreading involves the dynamic biological processes of actin polymerization and myosin contraction (39). The ability of cells to spread on a substrate surface may thus determine cell proliferation, quiescence, and death (39). Lee et al. (32) showed that round cells that displayed less spreading had lower proliferation rates than did flatter cells with greater spreading. As we described above, cell proliferation was significantly higher on a rough surface (Ti180) as compared with control. In addition, we used Ki-67 to confirm cell proliferation. Ki67 is an excellent cell proliferation marker due to its expression during all active phases of the cell cycle except the resting stage (40). Both Ti400 and Ti180 had higher expressions of Ki-67 in the nucleus, as shown in Fig. 6. Together, these findings suggest that rough surfaces promote adsorption of specific proteins, particularly fibronectin. These adsorbed proteins influence cell spreading behavior and thus enhance cell proliferation. Of course, additional studies are needed to test this hypothesis.

In conclusion, our results demonstrate that surface roughness affects cell spreading and proliferation, but not cell attachment, in human osteoblast-like cells. These findings indicate that modification of surface roughness might provide a more suitable microenvironment for early osteoblast response to implant materials.

\section{Acknowledgments}

The authors thank Anucharte Srijunbarl for his assistance in profilometry analysis. This study was supported by the Chulalongkorn University Centenary Academic Development Project and the Faculty of Dentistry, Chulalongkorn University Research Fund.

\section{References}

1. Eckert SE, Meraw SJ, Cal E, Ow RK (2000) Analysis of incidence and associated factors with fractured implants: a retrospective study. Int J Oral Maxillofac Implants 15, 662-667.

2. Cortizo AM, Bruzzone L, Molinuevo S, Etcheverry SB (2000) A possible role of oxidative stress in the vanadium-induced cytotoxicity in the MC3T3E1 osteoblast and UMR106 osteosarcoma cell lines. Toxicology 147, 89-99.

3. Lavos-Valereto IC, König B, Rossa C Jr, Marcantonio E Jr, Zavaglia AC (2001) A study of histological responses from Ti-6Al-7Nb alloy dental 
implants with and without plasma-sprayed hydroxyapatite coating in dogs. J Mater Sci Mater Med 12, 273-276.

4. Srimaneepong V, Yoneyama T, Wakabayashi N, Kobayashi E, Hanawa T, Doi H (2004) Deformation properties of Ti-6A1-7Nb alloy castings for removable partial denture frameworks. Dent Mater J 23, 497-503.

5. Aridome K, Yamazaki M, Baba K, Ohyama T (2005) Bending properties of strengthened Ti-6Al-7Nb alloy major connectors compared to Co-Cr alloy major connectors. J Prosthet Dent 93, 267-273.

6. Yamazoe J, Nakagawa M, Matono Y, Takeuchi A, Ishikawa K (2007) The development of Ti alloys for dental implant with high corrosion resistance and mechanical strength. Dent Mater J 26, 260-267.

7. Kobayashi E, Wang TJ, Doi H, Yoneyama T, Hamanaka H (1998) Mechanical properties and corrosion resistance of Ti-6Al-7Nb alloy dental castings. J Mater Sci Mater Med 9, 567-574.

8. Iijima D, Yoneyama T, Doi H, Hamanaka H, Kurosaki N (2003) Wear properties of Ti and Ti-6Al$7 \mathrm{Nb}$ castings for dental prostheses. Biomaterials 24, 1519-1524.

9. Rogers SD, Howie DW, Graves SE, Pearcy MJ, Haynes DR (1997) In vitro human monocyte response to wear particles of titanium alloy containing vanadium or niobium. J Bone Joint Surg $\mathrm{Br} 79$, 311-315.

10. Shimojo N, Kondo C, Yamashita K, Hoshino T, Hayakawa T (2007) Cytotoxicity analysis of a novel titanium alloy in vitro: adhesion, spreading, and proliferation of human gingival fibroblasts. Biomed Mater Eng 17, 127-135.

11. Pennekamp PH, Gessmann J, Diedrich O, Burian B, Wimmer MA, Frauchiger VM, Kraft CN (2006) Short-term microvascular response of striated muscle to cp-Ti, Ti-6Al-4V, and Ti-6Al-7Nb. J Orthop Res 24, 531-540.

12. Pennekamp PH, Wimmer MA, Eschbach L, Burian B, Koch P, Kraft CN (2007) Microvasculatory reaction of skeletal muscle to Ti-15Mo in comparison to well-established titanium alloys. J Mater Sci Mater Med 18, 2053-2060.

13. Osathanon T, Bespinyowong K, Arksornnukit M, Takahashi H, Pavasant P (2006) Ti-6Al-7Nb promotes cell spreading and fibronectin and osteopontin synthesis in osteoblast-like cells. J Mater Sci Mater Med 17, 619-625.

14. Balloni S, Calvi EM, Damiani F, Bistoni G, Calvitti M, Locci P, Becchetti E, Marinucci L (2009) Effects of titanium surface roughness on mesenchymal stem cell commitment and differentiation signaling. Int J Oral Maxillofac Implants 24, 627-635.

15. Wei D, Zhou Y, Yang C (2009) Structure, cell response and biomimetic apatite induction of gradient TiO2-based/nano-scale hydrophilic amorphous titanium oxide containing Ca composite coatings before and after crystallization. Colloids Surf B Biointerfaces 74, 230-237.

16. Mendonça G, Mendonça DB, Simões LG, Araújo AL, Leite ER, Duarte WR, Aragão FJ, Cooper LF (2009) The effects of implant surface nanoscale features on osteoblast-specific gene expression. Biomaterials 30, 4053-4062.

17. Aita H, Att W, Ueno T, Yamada M, Hori N, Iwasa F, Tsukimura N, Ogawa T (2009) Ultraviolet lightmediated photofunctionalization of titanium to promote human mesenchymal stem cell migration, attachment, proliferation and differentiation. Acta Biomater 5, 3247-3257.

18. Aita H, Hori N, Takeuchi M, Suzuki T, Yamada M, Anpo M, Ogawa T (2009) The effect of ultraviolet functionalization of titanium on integration with bone. Biomaterials 30, 1015-1025.

19. Schwartz Z, Raz P, Zhao G, Barak Y, Tauber M, Yao H, Boyan BD (2008) Effect of micrometer-scale roughness of the surface of Ti6Al4V pedicle screws in vitro and in vivo. J Bone Joint Surg Am 90, 24852498.

20. Nishimoto SK, Nishimoto M, Park SW, Lee KM, Kim HS, Koh JT, Ong JL, Liu Y, Yang Y (2008) The effect of titanium surface roughening on protein absorption, cell attachment, and cell spreading. Int J Oral Maxillofac Implants 23, 675-680.

21. Yamashita D, Machigashira M, Miyamoto M, Takeuchi H, Noguchi K, Izumi Y, Ban S (2009) Effect of surface roughness on initial responses of osteoblast-like cells on two types of zirconia. Dent Mater J 28, 461-470.

22. Pegueroles M, Aparicio C, Bosio M, Engel E, Gil FJ, Planell JA, Altankov G (2010) Spatial organization of osteoblast fibronectin matrix on titanium surfaces: effects of roughness, chemical heterogeneity and surface energy. Acta Biomater 6, 291-301.

23. Sader MS, Balduino A, Soares Gde A, Borojevic $R$ (2005) Effect of three distinct treatments of titanium surface on osteoblast attachment, proliferation, and differentiation. Clin Oral Implants Res 16, 667-675.

24. Le Guehennec L, Lopez-Heredia MA, Enkel B, 
Weiss P, Amouriq Y, Layrolle P (2008) Osteoblastic cell behaviour on different titanium implant surfaces. Acta Biomater 4, 535-543.

25. Vandamme K, Naert I, Vander Sloten J, Puers R, Duyck J (2008) Effect of implant surface roughness and loading on peri-implant bone formation. $\mathrm{J}$ Periodontol 79, 150-157.

26. Setzer B, Báchle M, Metzger MC, Kohal RJ (2009) The gene-expression and phenotypic response of hFOB 1.19 osteoblasts to surface-modified titanium and zirconia. Biomaterials 30, 979-990.

27. Lumbikanonda N, Sammons R (2001) Bone cell attachment to dental implants of different surface characteristics. Int J Oral Maxillofac Implants 16, 627-636.

28. Lemmerman KJ, Lemmerman NE (2005) Osseointegrated dental implants in private practice: a long-term case series study. J Periodontol 76, 310-319.

29. Mante M, Daniels B, Golden E, Diefenderfer D, Reilly G, Leboy PS (2003) Attachment of human marrow stromal cells to titanium surfaces. J Oral Implantol 29, 66-72.

30. Rosa AL, Beloti MM (2003) Effect of cpTi surface roughness on human bone marrow cell attachment, proliferation, and differentiation. Braz Dent J 14, 1621.

31. Rosa AL, Beloti MM (2003) Rat bone marrow cell response to titanium and titanium alloy with different surface roughness. Clin Oral Implants Res 14, 4348.

32. Lee TM, Tsai RS, Chang E, Yang CY, Yang MR (2002) The cell attachment and morphology of neonatal rat calvarial osteoblasts on the surface of Ti-6Al-4V and plasma-sprayed HA coating: effect of surface roughness and serum contents. J Mater Sci Mater Med 13, 341-350.
33. Deligianni DD, Katsala N, Ladas S, Sotiropoulou D, Amedee J, Missirlis YF (2001) Effect of surface roughness of the titanium alloy Ti-6Al-4V on human bone marrow cell response and on protein adsorption. Biomaterials 22, 1241-1251.

34. Park JW, Kim YJ, Jang JH, Kwon TG, Bae YC, Suh JY (2010) Effects of phosphoric acid treatment of titanium surfaces on surface properties, osteoblast response and removal of torque forces. Acta Biomater 6, 1661-1670.

35. Anderson JM, Rodriguez A, Chang DT (2008) Foreign body reaction to biomaterials. Semin Immunol 20, 86-100.

36. Nuttelman CR, Mortisen DJ, Henry SM, Anseth KS (2001) Attachment of fibronectin to poly(vinyl alcohol) hydrogels promotes NIH3T3 cell adhesion, proliferation, and migration. J Biomed Mater Res 57, 217-223.

37. Kim HJ, Kim SH, Kim MS, Lee EJ, Oh HG, Oh WM, Park SW, Kim WJ, Lee GJ, Choi NG, Koh JT, Dinh DB, Hardin RR, Johnson K, Sylvia VL, Schmitz JP, Dean DD (2005) Varying Ti-6Al-4V surface roughness induces different early morphologic and molecular responses in MG63 osteoblast-like cells. J Biomed Mater Res A 74, 366-373.

38. Horbett TA, Schway MB (1988) Correlations between mouse $3 \mathrm{~T} 3$ cell spreading and serum fibronectin adsorption on glass and hydroxyethylmethacrylate-ethylmethacrylate copolymers. J Biomed Mater Res 22, 763-793.

39. McGrath JL (2007) Cell spreading: the power to simplify. Curr Biol 17, R357-358.

40. Scholzen T, Gerdes J (2000) The Ki-67 protein: from the known and the unknown. J Cell Physiol $182,311-322$. 